\title{
BLOOD TYPE AND BLOOD PRESSURE CORRELATIONS TO BODY MASS INDEX IN YOUNG ADULTS
}

\author{
Bambang Edi Suwito ${ }^{2}$, Viskasari P. Kalanjati ${ }^{1}$, Abdurachman ${ }^{1}$ \\ ${ }^{1}$ Department of Anatomy and Histology, ${ }^{2}$ Faculty of Medicine, Universitas Airlangga, Surabaya, Indonesia
}

\begin{abstract}
Specific ABO blood type was reported to the higher risk of having overweight and obesity. The laters had also been suggested to correlate to blood pressure. Here we studied blood type and blood pressure amongst seemingly healthy university students of $I I K B W$, Kediri to understand their correlations to the body mass index (BMI). The blood typing (ABO typing, Eryclone $\left.{ }^{\circledR}\right)$ and blood pressure (automated digital sphygmomanometer) of 74 male and 76 female were measured in duplicate accordingly. The BMI was analysed from the student's body weight and height using a digital balance and a microtoise staturemeter, respectively. Data were analysed using SPSS 17 with $p<0.05$ level of significance. There were $18.7 \%$ students have A blood type, $31.3 \%$ students were B type, $44 \%$ were $O$ and $6.0 \%$ with AB blood type. There were $30.7 \%$ students with obesity, $18 \%$ overweight, $36 \%$ normal weight and $15.3 \%$ underweight. There were $4.7 \%$ had a hypertension, $28.7 \%$ pre-hypertension, and $66.7 \%$ were normal. No significant correlations found between BMI or the blood pressure to any specific ABO blood type, except between the blood pressure and the $A B$ blood type $(r=-0.179, p=0.03)$. However, there was a significant correlation between BMI and blood pressure $(r=0.327, p=0.000)$. We observed no significant associations between any specific ABO blood type with the BMI and blood pressure. However, high blood pressures amongst students with obesity were found. Males were more common to suffer from obesity and high blood pressure than females.
\end{abstract}

Keywords: Blood typing; hypertension; overweight

\section{ABSTRAK}

Golongan darah tertentu berisiko lebih tinggi mengalami kelebihan berat badan dan obesitas, serta berkorelasi dengan tingginya tekanan darah. Pada penelitian ini, golongan darah dan tekanan darah pada mahasiswa sehat di IIKBW, Kediri diteliti untuk memahami korelasinya dengan indeks massa tubuh (IMT). Golongan darah (alat ABO typing, Eryclone) dan tekanan darah (alat sphygmomanometer digital otomatis) dari 74 mahasiswa dan 76 mahasiswi diperiksa dengan prosedur yang terstandarisasi sesuai petunjuk manufaktur. IMT dianalisis dari berat badan dan tinggi siswa diukur menggunakan timbangan digital dan staturemeter microtoise. Data dianalisis menggunakan SPSS 17 dengan level signifikansi p<0,05. Terdapat 18,7\% mahasiswa dengan golongan darah A, 31,3\% tipe B, 44\% tipe O dan 6,0\% golongan darah AB. Sekitar 30,7\% mahasiswa tergolong obes, $18 \%$ kelebihan berat badan, 36\% normal dan 15,3\% kurus. Sebanyak 4,7\% tergolong hipertensi; 28,7\% pre-hipertensi, dan 66,7\% normal. Tidak terdapat korelasi signifikan antara BMI atau tekanan darah dengan golongan darah $A B O$ tertentu; kecuali antara tekanan darah dan golongan darah $A B(r=-0,179, p=0,03)$. Namun, terdapat korelasi signifikan antara BMI dengan tekanan darah $(r=0,327, p=0,000)$. Pada penelitian ini, tidak ada hubungan yang signifikan antara golongan darah ABO spesifik dengan BMI dan tekanan darah, namun tekanan darah yang tinggi ditemukan pada mahasiswa dengan IMT yang tinggi. Laki-laki lebih banyak menderita obesitas dan tekanan darah tinggi dibandingkan mahasiswa perempuan.

Kata kunci: Golongan darah; hipertensi; kelebihan berat badan

Correspondence: Viskasari P. Kalanjati, Departement of Anatomy and Histology, Faculty of Medicine,

Universitas Airlangga, Surabaya, Indonesia. E-mail: viskasari-p-k@fk.unair.ac.id

$\bullet$ pISSN:2355-8393 • eISSN: 2599-056x • doi: 10.20473/fmi.v56i3.24557

- Fol Med Indones. 2020;56:203-207 • Received 31 Jul 2019 • Accepted 9 Jan 2020

- Open access under CC-BY-NC-SA license • Available at https://e-journal.unair.ac.id/FMI/

\section{INTRODUCTION}

The ABO blood type has been widely studied throughout the world for many years, and various studies have confirmed its relationship with the higher risk of suffering from venous thrombosis (Bruzelius et al 2015), diabetes mellitus type 2 (Meigs et al 2004), hypertension and obesity (Chandra \& Gupta 2012, Hercegovac et al 2017). On the other hand, the obesity and the hypertension are becoming the non- 
communicable diseases with high morbidity and mortality rate. Obesity can be defined by the calculation of the Body Mass Index (BMI) that could be measured by the body weight and height. Whereas the hypertension is classified in various study; whereas in this study we used the classification by 8th Joint National Committee (JNC-8) guidelines on hypertension (Olin et al 2015).

Currently, Indonesia is experiencing a "double burden" period (Riskesdas, 2018). There is an increase in the prevalence of non-communicable chronic diseases accompanied by the persistence of infectious diseases. Hypertension and obesity are examples of noncommunicable chronic diseases, with increased trends amongst population including the young adults. According to Basic Health Research (Riskesdas) by the Ministry of Health (2018), there was an increased prevalence of hypertension from $25.8 \%$ in 2013 to $34.1 \%$ in 2018 ; the prevalence was $17.1 \%$ in the age group of 18-25 years (Widjaja et al 2013). Meanwhile, the prevalence of obesity in adults over 18 years has continued to increase in these 5 years periods. The prevalence amongst the 18-27 years population is about 9.7\% (Olin et al 2015).

To the best of our knowledge, there are limited study correlating the ABO blood type to the blood pressure and the BMI. Here we analyzed the ABO blood type and the blood pressure, also the BMI of the university students in Kediri to determine any correlations between these variables amongst the young adults in Indonesia.

\section{MATERIALS AND METHODS}

The study was conducted amongst 74 male and 76 female students of the Faculty of Dentistry, Institut Ilmu Kesehatan Bhakti Wiyata (IIKBW), Kediri, East Java, Indonesia GED 18-22 year old. Ethical clearance was obtained from the Research and Ethical Committee of Universitas Airlangga, Surabaya, Indonesia. The weight, height, waist circumference and hip circumference were measured using standard anthropometry. Body weight was measured to the nearest $0.1 \mathrm{~kg}$ using Omron HN289 (Omron, Japan) digital weighing scale placed on a firm, flat ground with subjects wearing light clothing and no shoes; belts and other accessories were removed and pockets emptied. Height was measured to the nearest $0.1 \mathrm{~cm}$ using a wall-mounted tape measure (GEA, Indonesia) with the subjects standing erect, barefoot, heels together and looking straight ahead in the Frankfurt plane. The BMI was calculated as weight in kilograms divided by height squared in metres. Blood groups are examined using the agglutination method (Eryclone ${ }^{\circledR}$ ABO grouping, Tulip India); the blood pressure was measured with a digital sphygmomanometer Omron HEM-7130 (Omron, Japan) twice in 5 minutes of interval according to the manufacture instructions. The Body Mass Index (BMI) is categorized according to the underweight category (BMI <18.5 kg/m2), normal weight (BMI 18.5 - 22.9 $\mathrm{kg} / \mathrm{m} 2)$, overweight (23-24.9 kg/m2) and obese (BMI> $25 \mathrm{~kg} / \mathrm{m} 2$ ), whereas blood pressure is categorized by normal $<120 /<80 \mathrm{mmHg}$, pre-hypertension (120139/80-89 mmHg, stage 1 hypertension (140-159/90-99 $\mathrm{mmHg})$ or stage 2 hypertension $(=160 /=100 \mathrm{mmHg})$ (WHO 2000, Olin et al 2015).

The BMI and blood pressure data in each blood group were tested using the Chi-Square; correlation between blood group, blood pressure and BMI were analysed using Spearman correlation test. Prevalence ratio was done to analyze the relative ratio of BMI and the blood pressure levels in males and females. Level of significance if $\mathrm{p}<0.05$ (SPSS 17).

\section{RESULTS}

There were 28 students with the A blood type, 47 students with the B blood type, 66 with $\mathrm{O}$ blood type and 9 with the $\mathrm{AB}$ blood type. There are $30.7 \%$ of all participants have an obesity $(n=46), 18 \%$ overweight $(\mathrm{n}=27), \quad 36 \%$ normal weight $(\mathrm{n}=54)$ and $15.3 \%$ underweight $(\mathrm{n}=23)$.

Based on their blood pressure, there were $4.7 \%$ had a hypertension stage 1 and $2(n=7), 28.7 \%$ had a prehypertension $(n=43)$, and the rest of the participants were within normal limits $(n=100)$ (Table 2).

There were no significant correlations either between the BMI and the A, B, O, AB blood type $(\mathrm{p}=0.186$, $p=0.465, p=1.000, p=0.722$, respectively); between the blood pressure and the $\mathrm{A}, \mathrm{B}, \mathrm{O}, \mathrm{AB}$ blood type ( $\mathrm{p}=0.711, \mathrm{p}=0.290, \mathrm{p}=0.861, \mathrm{p}=0.03$; respectively) (table 3). In AB blood type however, all 9 participants have normal blood pressure $(\mathrm{r}=-0.179, \mathrm{p}=0.03)$ (Table 3).

In this study, there was a positive significant correlation between the BMI and the blood pressure $(r=0.327$, $\mathrm{p}=0.000$ ) (table III). When compared between genders, there is a significant different in the blood pressure $(\mathrm{p}=0.016)$, and also in the BMI $(\mathrm{p}=0.001)$. Students with obesity have 1.6 times higher risk to suffer from increased blood pressure; males had 1.5 times higher risk to develop obesity and were 1.3 times more at risk to have a high blood pressure than females. 
Table 1. The BMI, blood pressure and the blood type of all students

\begin{tabular}{llccccc}
\hline & & \multicolumn{2}{c}{ Blood Type (n) } & \multirow{2}{*}{ Total (n) } \\
\cline { 3 - 6 } & & A & B & O & AB & \\
\hline BMI & Underweight & 2 & 14 & 6 & 1 & 23 \\
& Normal & 9 & 17 & 25 & 3 & 54 \\
& Overweight & 5 & 4 & 15 & 3 & 27 \\
& Obesity & 12 & 12 & 20 & 2 & 46 \\
Total & & 28 & 47 & 66 & 9 & 150 \\
BP & Normal & 20 & 28 & 43 & 9 & 100 \\
& Prehypertension & 5 & 16 & 22 & 0 & 43 \\
& Hypertension Stage & 1 & 2 & 1 & 0 & 4 \\
& I & & & & & 3 \\
& Hypertension Stage & 2 & 1 & 0 & 0 & \\
Total & II & 28 & 47 & 66 & 9 & 150 \\
\hline
\end{tabular}

Table 2. The BMI, blood pressure and gender of all students

\begin{tabular}{llccc}
\hline & & \multicolumn{2}{c}{ Sex } & \multirow{2}{*}{ Total } \\
\cline { 3 - 4 } & & Male & Female & \\
\hline BMI & Underweight & 12 & 11 & 23 \\
& Normal & 24 & 30 & 54 \\
& Overweight & 8 & 19 & 27 \\
\multirow{3}{*}{ Total } & Obesity & 30 & 16 & 46 \\
BP & Normal & 74 & 76 & 150 \\
& Prehypertension & 39 & 61 & 100 \\
& Hypertension Stage & 2 & 12 & 43 \\
& I & & 2 & 4 \\
& Hypertension Stage & 2 & 1 & 3 \\
Total & II & & & \\
\hline
\end{tabular}

\section{DISCUSSION}

We observed quite a high prevalence of obesity amongst these students. This prevalence is higher when compared to those of Riskesdas (Riset Kesehatan Dasar, Indonesia) 2018 and to the previous studies in other developing countries (Vikrant 2001, Peltzer et al 2014, Aguilar \& Fernandez 2014). However, our study was in accordance to what has been reported by Peltzer et al (2014), where $20 \%$ of males and $10.7 \%$ of females out of 15,746 students were detected with obesity (Peltzer et al 2014). Obesity produces from combination of adipocyte dysfunction and triglyceride overload (Aguilar \& Fernandez 2014). It is correlated to hypertension. Obesity may compromise hyperinsuline- mia and peripheral resistance that elevated blood pressure (Vikrant 2001).

The prevalence of high blood pressure in this study was in accordance to those of Riskesdas 2018, with a close number of above $30 \%$. In other previous study conducted in the rural area in Indonesia. The prevalence was approximately $34.2 \%$ in males and $17.1 \%$ in females (Widjaja et al 2013). The significant correlation between the BMI and the blood pressure had been reported previously. There is a relative hyperinsulinemia due to increased lipolysis of the abdominal fat thus the release of free fatty acids. This would result in sodium retention, increased sympathetic nervous activity and vascular hypertrophy. 
Table 3. Correlation of BMI, Blood Pressure and Blood Grouping of all Students

\begin{tabular}{|c|c|c|c|c|c|c|c|c|}
\hline & & \multicolumn{2}{|c|}{ BMI } & \multicolumn{5}{|c|}{$\mathrm{BP}$} \\
\hline & & Obesity & $\begin{array}{l}\text { Non- } \\
\text { Obesity }\end{array}$ & $\mathrm{p}$ & $\begin{array}{c}\text { Elevated } \\
\text { BP }\end{array}$ & Normal BP & $\mathrm{r}$ & $\mathrm{p}$ \\
\hline \multirow[t]{10}{*}{$\begin{array}{l}\text { Blood } \\
\text { Group }\end{array}$} & $\begin{array}{l}\text { A Blood } \\
\text { Group }\end{array}$ & 12 & 16 & 0.186 & 8 & 20 & & 0.711 \\
\hline & $\begin{array}{l}\text { Non-A Blood } \\
\text { Group }\end{array}$ & 34 & 88 & & 42 & 80 & & \\
\hline & B Blood Group & 12 & 35 & 0.465 & 19 & 28 & & 0.290 \\
\hline & $\begin{array}{l}\text { Non-B Blood } \\
\text { Group }\end{array}$ & 34 & 69 & & 31 & 72 & & \\
\hline & $\begin{array}{l}\text { O-Blood } \\
\text { Group }\end{array}$ & 20 & 46 & 1.000 & 23 & 43 & & 0.861 \\
\hline & $\begin{array}{l}\text { Non-O Blood } \\
\text { Group }\end{array}$ & 26 & 58 & & 27 & 57 & & \\
\hline & $\begin{array}{l}\text { AB Blood } \\
\text { Group }\end{array}$ & 2 & 7 & 0.722 & 0 & 9 & -0.179 & 0.030 \\
\hline & $\begin{array}{l}\text { Non-AB Blood } \\
\text { Group }\end{array}$ & 44 & 97 & & 50 & 91 & & \\
\hline & Obesity & & & & 26 & 20 & 0.327 & 0.000 \\
\hline & Non-Obesity & & & & 24 & 80 & & \\
\hline
\end{tabular}

In the obesity, the peripheral insulin resistance occurs and attenuates the vasodilatation. These would produce hypertension, especially in patients with diabetes mellitus type 2 (Vikrant 2001).

Here we did not find any significant correlations between each ABO blood type either to the BMI or to the blood pressure. Previous study in Saudi Arabia and Ghana had reported that there was no correlation between the ABO blood grouping to the BMI (Alwasaidi et al 2017) or to the blood pressure (Abdollahi et al 2009). The ABO blood type is the method to determine the blood group of a person through the agglutination methods or molecular imprinting (Mujahid \& Dickert 2015). In other previous studies, it has been reported that the B blood type has more susceptible to hypertension and obesity (Chandra \& Gupta 2012); whilst type A or AB relatively more resistance to high blood pressure. One of proposed mechanism is that ABO genes rs495828 decreases the ACE (angiotensin converting enzyme), thus lowering the conversion of angiotension-I to angiotension-II which could decrease the hypertension risk. This property owed to the minor allele $\mathrm{T}$ that is strongly correlated to the $\mathrm{ABO}$ phenotype and with the expression of glycosyltransferase isoform $\mathrm{A}$; this glycosylation would in turn affect the ACE activity where the $\mathrm{O}$ allele does not have (Gassó et al 2014).

\section{CONCLUSION}

Although no significant correlations between the ABO blood type to either the BMI or the blood pressure, there is a significant correlation between the BMI and the blood pressure amongst these students. There was also an increased risk of having obesity and high blood pressure in males when compared to the females.

\section{ACKNOWLEDGMENT}

Thank you to all participants and the IIKBW, Kediri. The authors declare that there is no conflict of interests.

\section{REFERENCES}

Abdollahi, A., Qorbani, M., Salehi, A., Mansourian, M (2009). ABO Blood Groups Distribution and Cardiovascular Major Risk Factors in Healthy Population Iranian J Publ Health 38, 123-126.

Aguilar D, Fernandez ML (2014). Hypercholesterolemia induces adipose dysfunction in conditions of obesity and nonobesity. Adv Nutr 5, 497-502.

Alwasaidi TA, Alrasheed SK, Alhazmi RA, Alfraidy OB, Jameel MA, Alandijani AA (2017). Relation between $\mathrm{ABO}$ blood groups and obesity in a Saudi 
Arabian population. J Taibah Univ Med Sci 12,407411.

Bruzelius M, Bottai M, Sabater-Lleal M, Strawbridge RJ, Bergendal A, Silveira A, et al (2015). Predicting venous thrombosis in women using a combination of genetic markers and clinical risk factors. Journal of Thrombosis and Haemostasis 13, 219-227.

Chandra T, Gupta A (2012). Association and Distribution of Hypertension, Obesity and ABO Blood groups in Blood Donors. Iran J Pediatr Hematol Oncol 2,140-145.

Gassó P, Ritter MA, Mas S, Lafuente A (2014). Influence of $\mathrm{ABO}$ genotype and phenotype on angiotensin-converting enzyme plasma activity. Journal of the Renin-Angiotensin-Aldosterone System $15,580-584$.

Hercegovac A, Hajdarevic E, Hodžic S, Halilovic E, Avdic A, Habibovic M (2017). Blood group, hypertension, and obesity in the student population of northeast Bosnia and Herzegovina. In: Badnjevic A (ed) CMBEBIH 2017. Springer Singapore 62, 774777.

Kementerian Kesehatan, Indonesia, 2018. Hasil Utama Riskesdas. Badan Penelitian dan Pengembangan Kesehatan (Balitbangkes), Indonesia. Available at www.depkes.go.id/resources/download/infoterkini/hasil-riskesdas-2018.pdf. Accessed May 25th, 2019

Meigs JB, Hu FB, Rifai N, Manson JAE (2004). Biomarkers of Endothelial Dysfunction and Risk of Type 2 Diabetes Mellitus. J Am Med Assoc 291, 1978-1986.
Mujahid A, Dickert FL (2015). Blood group typing: from classical strategies to the application of synthetic antibodies generated by molecular imprinting. Sensors 16, 51. Available at https://www.ncbi.nlm.nih.gov/pmc/articles/PMC4732 084/pdf/sensors-16-00051.pdf. Accessed May 27th,2019

Olin BR, Twiggs J, Bell K (2015). Hypertension: The silent killer: Updated JNC-8 guideline recommendations. Alabama Pharm Assoc. Available at www.aparx.org Accessed May 27, 2019

Peltzer K, Pengpid S, Samuels T, Özcan N, Mantilla C, Rahamefy O, et al (2014). Prevalence of Overweight/Obesity and Its Associated Factors among University Students from 22 Countries. International Journal of Environmental Research and Public Health 11, 7425-7441

Vikrant S, Tiwari S (2001). Essential Hypertension Pathogenesis and Pathophysiology', Journal, Indian Academy of Clinical Medicine, 2, 140 - 161

Widjaja F F, Santoso LA, Barus NRV, Pradana GA, Estetika C (2013). Prehypertension and hypertension among young Indonesian adults at a primary health care in a rural area. Medical Journal of Indonesia 22, $39-45$.

World Health Organization (2000). The Asia-Pacific perspective: redefining obesity and its treatment. Geneva: World Health Organization. Available at http://www.wpro.who.int/nutrition/documents/Redefin ing_obesity/en/. Accessed May 25th, 2019. 